\title{
RESEARCH/ARAȘTIRMA
}

\section{WOMEN'S EXPERIENCES OF VAGINAL EXAMINATION DURING NORMAL CHILDBIRTH AND AFFECTING FACTORS: A QUALITATIVE STUDY ${ }^{1}$}

\author{
Gülnur YILDIRIM ${ }^{2}$ id Nevin ÇITAK BILGIN ${ }^{3}$
}

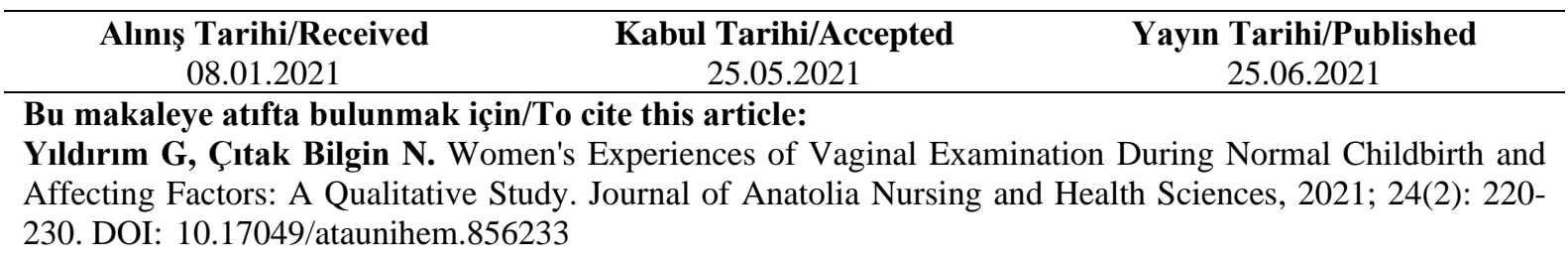

\section{ABSTRACT}

Aim: This study aims to determine qualitatively experiences and affecting factors of the women related to vaginal examination during labor.

Methods: The study was conducted with 20 normal birth giving women at two state hospitals in a province in Turkey. The data were collected by personal information form, semi-structured interview form and interviewer observation form. The data were analyzed by the content analysis.

Results: The average age of women was $34.60 \pm 6.40$, and $75 \%(n: 15)$ of them were multiparous. Two themes were identified as "vaginal examination concept" and "experience and emotional reactions related to the vaginal examination." The themes affecting the vaginal examination experience were also determined as "affecting life" and "expectations on vaginal examination." The participants often declared that the examination was performed to assess the progression of childbirth. They also stated that they did not get enough information from the healthcare professionals during the examination process. They declared that the professionals did not pay enough attention to their privacy, and they were exposed to unnecessary and frequent vaginal examinations. According to the results, most of their experiences were negative (especially feelings of shame, pain and loneliness). The healthcare professionals were expected to be friendly and informative. The examination environment was expected to be appropriate in terms of ergonomics.

Conclusion: Women expect special attention for their physical and psycho-social care needs during vaginal examination.

Keywords: Birth; gynecological examination; nursing care; women's health.

\section{$\ddot{O} Z$}

Kadınların Normal Doğum Sürecinde Vajinal Muayeneye İlişkin Deneyimleri ve Etkileyen Faktörler: Nitel Bir Araștorma

Amaç: Bu çalışma kadınların doğum sırasında vajinal muayeneye ilişkin deneyimlerini ve etkileyen faktörleri nitel olarak belirlemek amactyla yapılmuştır.

Yöntem: Çallşma Türkiye'de bir ildeki iki devlet hastanesinde normal doğum yapan 20 kadın ile yapllmıştrr. Veriler kişisel bilgi formu, yarı yapılandırılmış görüşme formu ve görüş̧meci gözlem formu ile toplanmıştır. Veriler içerik analizi kullanilarak analiz edilmiştir.

Bulgular: Kadınların yass ortalaması $34.60 \pm 6.40$ olup, $\% 75^{\prime} i$ (n: 15) multipard. Çalışmada vajinal muayene deneyimine ilişkin "vajinal muayene kavramı" ve "vajinal muayeneye iliskkin deneyim ve duygusal tepkiler" olarak iki tema belirlenmişstir. Vajinal muayene deneyimini etkileyen faktörlere ilişsin temalar ise "yaşantiyı etkileyenler" ve "vajinal muayene ile ilgili beklentiler" olarak belirlenmişstir. Katıllmcılar sıklikla muayenenin doğumun ilerleyişini değerlendirmek için yapıldı̆̆ın ifade etmişlerdir. Kadınlar aynı zamanda muayene sürecinde sağllk çalışanlarından yeterli bilgi almadıklarını, sağllk profesyonellerinin mahremiyetlerine yeterince dikkat etmediklerini, gereksiz ve slk vajinal muayeneye maruz kaldlkların söylemişlerdir. Çalışma sonucuna göre, kadınların vajinal muayene deneyimlerinin çoğunlukla olumsuz olduğu görülmüş̧tür (özellikle utanma, ă̆rl ve yalnzzlık hissi). Katıllmcılar sağllk profesyonellerinden öncelikle güler yüzlü ve bilgilendirici olmalarını beklerken, muayene ortaminın ise ergonomik açıdan uygun olmasını beklediklerini ifade etmişlerdir.

Sonuç: Kadınlar vajinal muayene sırasında fiziksel ve psiko-sosyal bakım gereksinimlerinin karşılanmasına önem verilmesini beklemektedir.

Anahtar kelimeler: Doğum; jinekolojik muayene; hemşirelik bakımı; kadın sağlı̆̆t.

${ }^{1}$ This study has been produced from master theses. Study was presented as an oral presentation between 19 and 21 December 2019 at the 6th International 17th National Nursing Congress in Ankara, Turkey.

${ }^{2}$ Bolu Abant Izzet Baysal University, Izzet Baysal Training and Research Hospital, (Msc, Midwife), ORCID: 0000-0001-5022-8319, e-posta: gulnursyildirim@ hotmail.com

${ }^{3}$ Sorumlu Yazar: Bolu Abant Izzet Baysal University, Faculty of Health Sciences, Department of Obstetrics and Gynecology Nursing, (RN, PhD), ORCID: 0000-0003-4367-215X, e-posta: nevincitak@ yahoo.com 


\section{INTRODUCTION}

Women are exposed to a number of obstetric medical practices throughout the childbirth, and thus they obtain complex feelings about the birth process (1). Vaginal examination (VE) is, in this respect, one of the frequently performed procedures. Majority of women often experience their first VE during pregnancy or childbirth. VE during the delivery process is a common practice in making important clinical decisions related to the labor progression (2). The health professionals can obtain information about the crucial clinical requirements such as the cervical effacement and dilatation, fetal position, station, condition of membranes with the aid of VE $(3,4)$. The examination can be anticipated as a decision making-process about whether the vaginal labor (spontaneous/intervention delivery, delivery time and epidural analgesia use or not) will be performed or not (4). World Health Organization (WHO) recommends the VE is performed at 4hour intervals for the routine evaluation at the childbirth (5), nevertheless, the studies show that the women are unduly exposed to more examinations than suggested $(4,6)$. Although the VE takes much less time as compared to other physical examinations, most of women do not like it, and in fact they are afraid and especially feel ashamed due to their privacy emotions (7). While VE plays an important role in determining the course of labor, the pregnant women define the term as painful, stressful, excitement, feelings of loneliness, shame, embarrassment, nervousness and fear (8). The negative feelings and experiences in the memories of women against vaginal examination remain remarkably (9). It is emphasized that the negative experiences affect the fertility preferences of women and create fear about vaginal labor (10).

Physical, mental and emotional support to the women during the childbirth is regarded as the most important duty of health professionals. This support constitutes vital parts of the labor. Studies show that the supportive care provided in the $\mathrm{VE}$ is enable the pregnant women not only to fulfill in the motherhood role and increase in the self-esteem of women, but also to contribute to the positive birth experience (11).

However, some studies show that not all the interventions in the labor are supportive enough (4,6). Several studies state that the pregnant women have encountered the negative feelings and experiences including the rude and uninterested attitudes of health professionals, insufficient privacy, improper examination position, lack of examination experience, hospital environment, previous negative (painful and aches) examination experiences, use of inappropriate instruments and lack of information about the examination $(7,8,12)$.

Midwives and nurses have important duties in the protection and maintenance of women's health. Protection of privacy, being informative, being friendly and respectful attitudes of health professionals are important in the process of $\mathrm{VE}(3,13)$. Most women do not feel safe, unless these have been provided (14). Sufficient information, polite and understanding attitudes during the VE may increase the women's the sense of control and provide them with a positive birth experience $(11,15)$.

Although there are qualitative and quantitative studies about $\mathrm{VE}$ experience of women at vaginal birth in the world $(4,8,12,13)$, there are quite limited studies in Turkey $(7,14)$. Knowing the examination experience of women in the intrapartum period may be considered as an opportunity in terms of evaluating and improving the services provided.

\section{METHODS}

Participants: The study was conducted between July and September 2017 in the maternity ward services of two state hospitals in a province in northern Turkey. Criterion sampling method, one of the purposeful sampling techniques, was used to determine the sample of the current study. Accordingly, women giving normal birth, being the primipar or multipar, giving a healthy and term baby, speaking Turkish, presenting no communication problems, having no psychiatric problems, volunteering to participate in the survey were included in the study. Data was collected until the data saturation was reached. In study, the data saturation was achieved with 20 women. The data saturation has widely been used as a methodological principle in the qualitative research and accordingly is a kind of indicators to define whether the adequacy of data collected and analyzed is adequate or not $(16,17)$.

Data collection tools: The data were collected by personal information form, semistructured interview form and interviewer observation form.

Personal information form: This form consists of totally nine questions. The primary contribution of the first five questions is to determine the socio-demographic characteristics as regards the 
age, marriage age, educational status, occupation, monthly income of participants whereas the last four questions ascribe to define the number of pregnancies, miscarriage/abortions, parity and previous VE experiences.

Semi-structured interview form and interviewer observation form: Semi-structured interview form was prepared according to the literature $(1,3,4,8,13)$. The form included questions evaluating the VE experience, factors affecting the experience and expectations. The interviewer observation form includes the code number (W1, $\mathrm{W} 2$, W3 etc) indicating the interviewed person, the place of interview, date, time and the parts containing the behavior of women during the interview recorded.

Data collections: The data were collected by face-to-face and in-depth individual interview method. Before the formal interviews, the researcher had a short informal conversation with the participants to build trust (18). The interviews were conducted in the postpartum period, before the discharge, in a comfortable and private environment. Each session lasted approximately 30-45 minutes. Pre-application has been performed with three participants. The interviews were held with the participants alone. The participants were informed that their names would be kept confidential, and the interviews were conducted by providing the code name (W1, W2 etc.). During the interview, no restrictions were imposed on the responses of participants. Audio voice recordings were used to make the analysis healthier. It was explained that only the researchers will listen to the voice recordings, they will not be shared, and the voice recording can be turned off at any time during the interview. Interviews completed with 20 women who accepted use of voice recorder. Some notes about the participant's body language were recorded on the interviewer observation form while the participant was interviewing.

Data analysis: The data were analyzed by the content analysis. Voice recordings and notes taken during the interview were transferred to the personal computer at the end of the interview, and they were edited and then written by the researcher. While reading the text, meaningful sentences or expressions were combined by underlying according to their semantic similarities expressed conceptually, and the code names to represent these views were formed. Here, the codes are tabulated with respect to the frequency of spelling. Sub-themes and themes representing the codes were determined. Codes and themes were created by reading the text separately by two expert researchers. After then, the reliability of the themes and codes was improved by comparing the content analysis of two researchers.

Ethics: This study was conducted in accordance with the principles of Helsinki Declaration. Ethical approval for the study was obtained from University's Clinical Researches and Ethics Committee (dated:23.06.2017, no:151) and where the study was held (dated:2017, no:774.09). Women were informed about the contents of research, voluntary of participation, their rights to withdraw from the study, confidentiality of participant information and their answers to be used for only this research. They were informed that a voice recorder would be used during the interview, and they could stop recording whenever they wish. In this context, written consents of all the participants were obtained.

\section{FINDINGS AND DISCUSSION}

The survey results were collected in three main headings: (I) findings about the personal characteristics of women, (II) findings related to the VE experiences of women and (III) affecting factors for the experiences of VE.

\section{Personal characteristics of women}

Personal profile information on the sociodemographic and obstetric characteristics of participants was given in Table 1 .

The mean age of participants was $34.60 \pm$ 6.40 and the mean age of marriage was $22.35 \pm$ 3.43 years. $55 \%$ of women (n:11) were graduated from secondary school, $70 \%$ (n: 14) were housewives, $90 \%$ (n: 18) had a higher income than minimum monthly wage. As for obstetric features; $40 \%$ (n: 8) had three or more pregnancies, $75 \%$ of (n: 15) were multiparous, $20 \%$ (n: 4) had abortion/miscariage history and 85\% (n: 17) had a previous VE experience.

\section{experience}

Findings related to vaginal examination

The experiences related to the VE of women are presented under two themes, four sub-themes and 21 codes as shown in Figure 1. Figure 1 insert here.

\section{Theme I. Vaginal examination concept}

Sub Theme 1: Meaning of vaginal examination: Most of participants (n: 10) thought that the VE was performed both to find out the progression of labor and to get the required information about cervical patency. One of the 
participants expressed her opinion as "The first thing that comes to mind for the VE is the childbirth (laughing). The gynecologist examined whether the birth is approaching and any opening for cervical patency or not" (W-4).

Theme II. Experience and emotional reactions

The second theme of "experience and emotional reactions" is classified in 3 sub-themes and the related codes as shown in Figure 1.
Sub Theme 1: Positive experiences: Majority of the participants (n: 8) felt lucky to receive care from the same health care professional during VE and other interventions. So, the participants thought as follows: "I was very happy that the same midwife took care of me. She was very helpful during the examination." (W-14), "The midwife at the maternity ward was very good. I mean, I have been so pleased that the same midwife examined me. God bless her" (W-6).

Table 1. Distribution of women according to socio-demographic and obstetric characteristics $(n=20)$

\begin{tabular}{|c|c|c|}
\hline $\begin{array}{l}\text { Socio-demographic and } \\
\text { obstetric characteristics }\end{array}$ & n / Mean \pm SD & $\%$ \\
\hline \multicolumn{3}{|l|}{ Age (year) } \\
\hline $20-30$ & 4 & 20.0 \\
\hline $31-45$ & 16 & 80.0 \\
\hline Average age & $34.60 \pm 6.40$ & $(\min .: 20, \max .: 45)$ \\
\hline \multicolumn{3}{|l|}{ Age of marriage } \\
\hline $17-20$ & 8 & 40.0 \\
\hline $21-24$ & 7 & 35.0 \\
\hline $25-28$ & 5 & 25.0 \\
\hline Average age of marriage & $22.35 \pm 3.43$ & $(\min .: 17, \max .: 28)$ \\
\hline \multicolumn{3}{|l|}{ Education } \\
\hline Primary school & 3 & 15.0 \\
\hline Secondary school & 11 & 55.0 \\
\hline High school & 5 & 25.0 \\
\hline University & 1 & 5.0 \\
\hline \multicolumn{3}{|l|}{ Occupation } \\
\hline Housewife & 14 & 70.0 \\
\hline Officer & 2 & 10.0 \\
\hline Worker & 4 & 20.0 \\
\hline \multicolumn{3}{|l|}{ Monthly wage } \\
\hline$\leq 1404$ Turkish Liras & 2 & 10.0 \\
\hline$>1405$ Turkish Liras & 18 & 90.0 \\
\hline \multicolumn{3}{|l|}{ Number of pregnancy } \\
\hline$\leq 2$ & 12 & 60.0 \\
\hline$\geq 3$ & 8 & 40.0 \\
\hline \multicolumn{3}{|l|}{ Abortions/ miscarriage } \\
\hline None & 16 & 80.0 \\
\hline 1 & 3 & 15.0 \\
\hline 2 & 1 & 5.0 \\
\hline \multicolumn{3}{|l|}{ Parity } \\
\hline Primipara & 5 & 25.0 \\
\hline Multipara & 15 & 75.0 \\
\hline \multicolumn{3}{|c|}{ Previous vaginal examination status } \\
\hline No & 3 & 15.0 \\
\hline Yes & 17 & 85.0 \\
\hline Total & 20 & 100.0 \\
\hline
\end{tabular}

Some participants (n: 8) declared that the health professionals supported them positively. One stated this support as; "There were midwives and two nurses during my labor. They all were very good (especially emphasizing). They were very helpful and supportive to me.
They made me so relaxed. I cannot forget those moments and I tell my relatives. I hope everyone is examined by such midwifes and nurses" (W 12).

Sub Theme 2: Negative experiences: Most of women (n: 12) described the frequent VEs as 
negative experiences. The participants expressed their negative experiences resulting from the frequent VEs. Namely, "The examination was performed for every 10-15 minute. It was very uncomfortable and bothering me." (W-18), "The health professionals came for another examination in every ten minutes. Hmm, the professionals constantly controlled me using the fingers during the labor. It annoyed me" (W-3).

Negative experiences (n: 11) for not ensuring privacy were as; "Even, you have

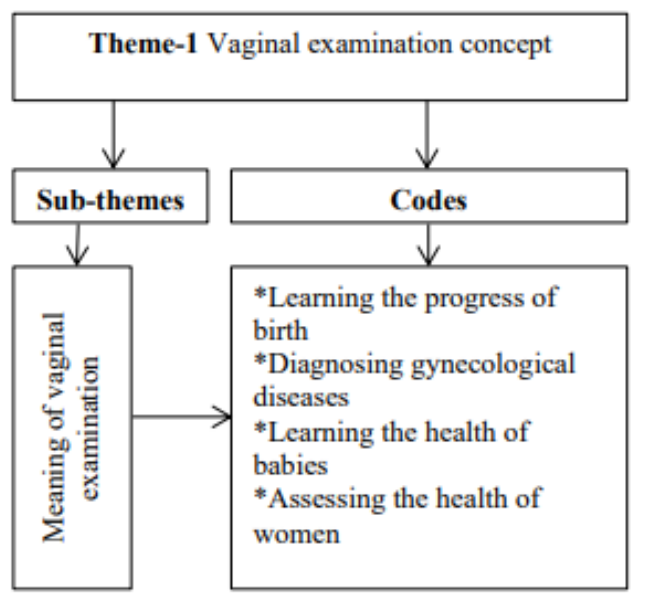

already felt bad. It was so crowded. Besides, I was lying on the birth (mn lithotomy) table during the examination. It was too bad that the others easily come and look at me. It made me feel so bad." (W-10), "There were students during the examination. They were always used to observing the examination. One was examining and then another one was coming to examine and so on. I thought the privacy was not important" (W-11).

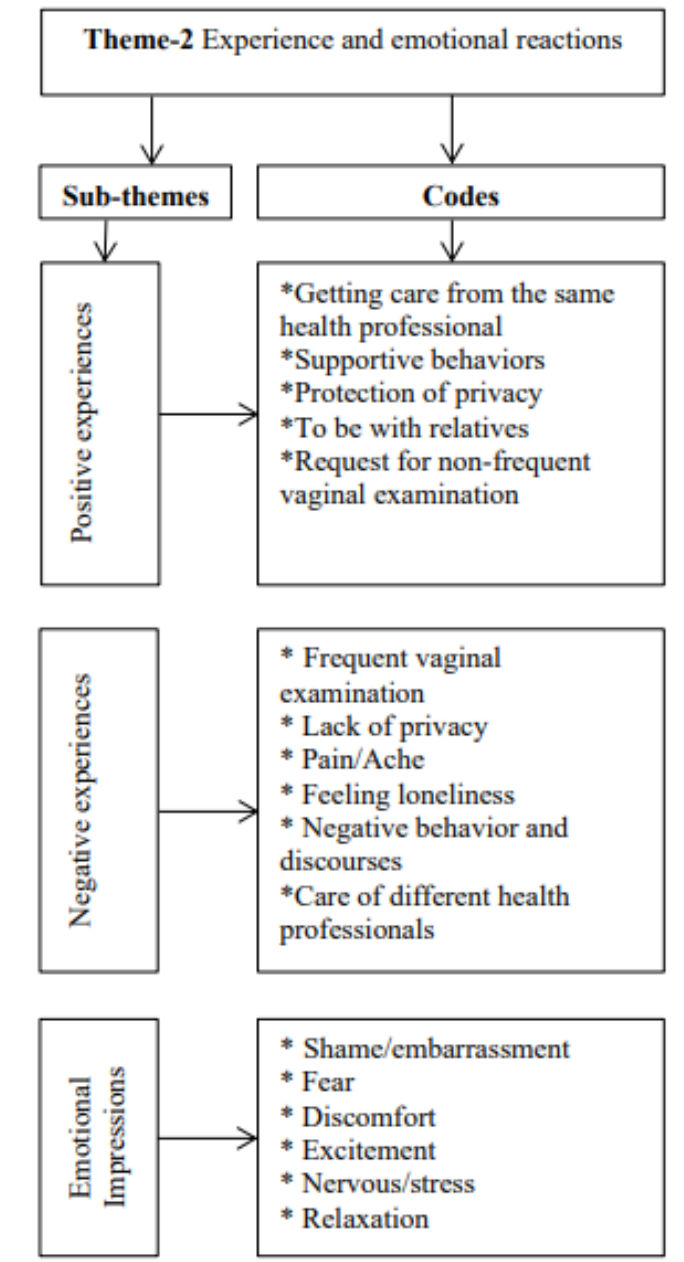

Fig 1. Vaginal examination experience.

Some participants (n:9) declared that they felt lonely and had pain/aches during VE (n:9). They stated their loneliness as; "I wanted my mother with me throughout the VE. However, they did not let her come in. It was my opinion that no one should feel alone in the examination." (W-8), "Nobody was with me and I felt alone. I wished that my spouse were with me. Especially, I wish he had supported me during my examinations" (W-17).

Sub Theme 3: Emotional impressions: Shame/ embarrassment was found to be the most common emotion for the women (n:17) during the VE. The statements of participants regarding the shame/ embarrassment were as; "I was ashamed and very disturbed. The health professionals wanted us to take our underwear off. There was only a screen between me and the other women, and we were examined. They of course covered us by the sheets. But how can I tell you? I felt being on thorns" (W-8), "O $f$ course I was ashamed of people because I was naked" (W-13). 
Fear was another common emotion experienced (n: 13) during the VE. As for the emotions given in the individual interviews; "I was afraid and nervous due to the VE" (W-3), "The examination trembled me, hence I was scared. I felt so bad myself because they examined from below" (mn. the vagina) (W-20).
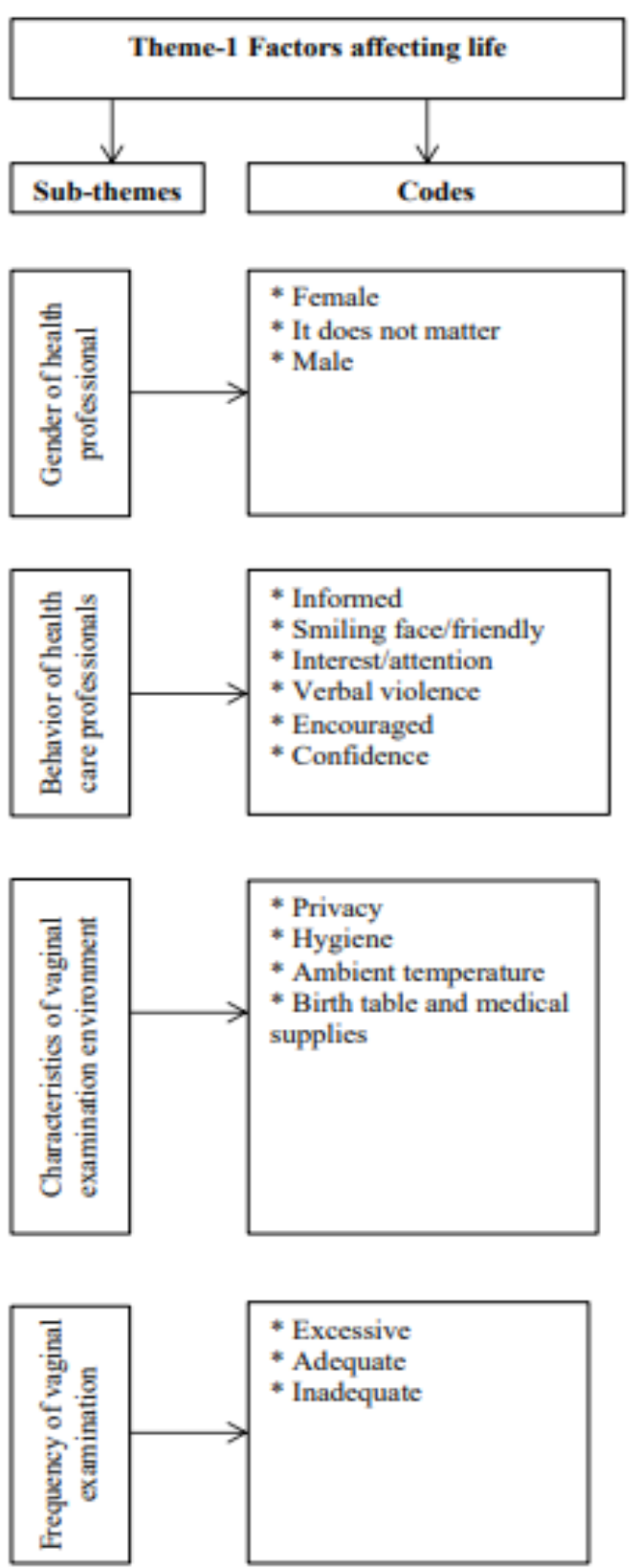

Findings related to factors affecting vaginal examination experience

Affecting factors for the VE experience of women are presented under two themes, seven sub-themes and 33 codes as in Figure 2.
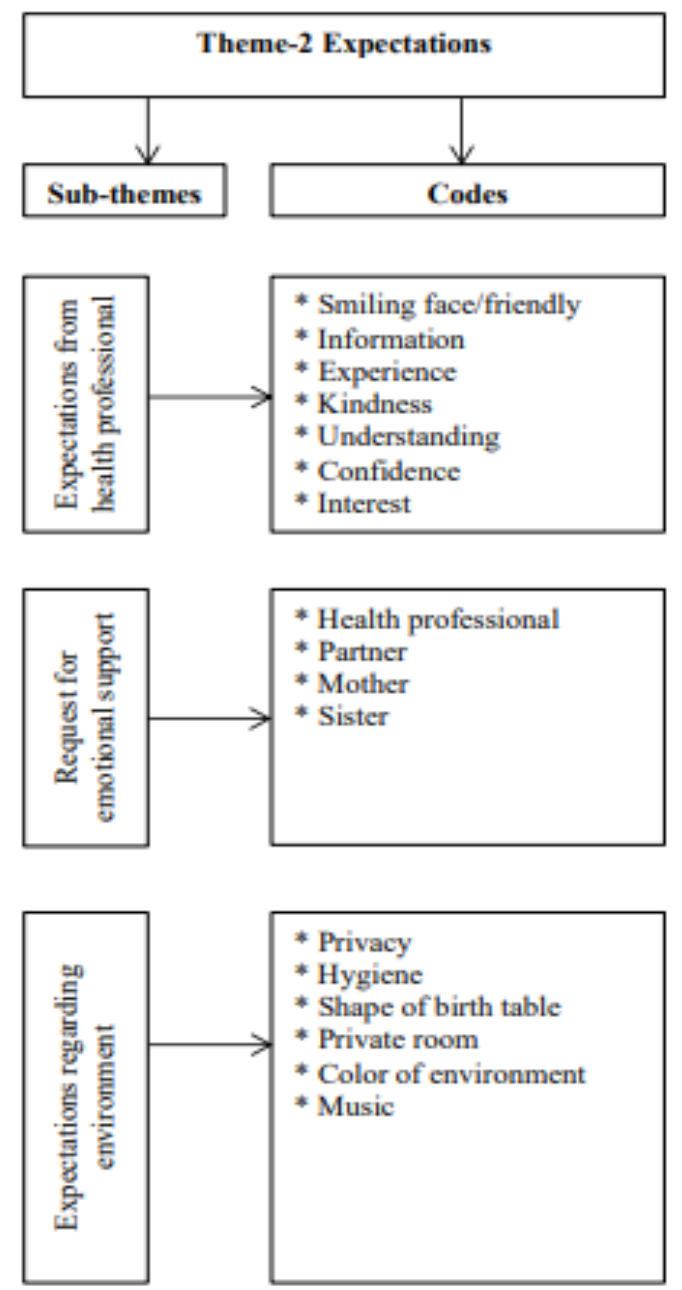

Fig 2. Factors affecting vaginal examination experience and expectations.

\section{Theme I. Factors affecting life}

Sub Theme 1: Gender of health professional: The majority of participants (n:13) stated that they preferred the VE to be performed by female health professionals. Namely; " $O f$ course, I felt much closer to the women. I was more embarrassed than men compared to women" (W-1), "I preferred female health professionals. I am embarrassed by the male doctor while I am even ashamed of my own husband and I am examined by obligation" (W2). 
Sub Theme 2: Behavior of health care professional: It was found that the women (n: 16) cared about being informed about the VE. The majority of these women (n: 10) believed that they were provided with insufficient information about the examination. As; "The health professionals talked to each other about the birth of the baby while they were examining. They gave me no information. When I asked they only said soon" (W-13). Some of participants $(n: 6)$ stated that they were satisfied with the information provided during the examination. That is; "The health professionals gave information about the examination at every stage, thus I would like to visit to thank them after being much better" (smiling) (W-1).

The participants stated whether or not the healthcare professional were friendly (n: 11) and how their behavior affected the VE experience. Some of participants (n: 7) declared that the health professionals were not friendly during VEs. In more detail, "They were not very positive and behaved very badly." (W-3), "I was scared for being rebuked at the examination. They were no smoothie" (W-18). Some of participants were pleased that the health professionals were friendly. Namely, "I had midwives and nurses in my VE. All were very smiling and gave me positive energy" (W-12).

Seven of women thought that the health professionals used verbal violence during the examination and eight of them stated that they were treated irrelevant.

One participant said; "Even though I called them, they did not come to examine me. They came at the last minute and all scolded me. I was so nervous because they were so indifferent" (W-2).

Sub Theme 3: Characteristic of vaginal examination environment: The majority of women (n: 14) pointed to the privacy of VE. One of the participants stated that it should be paid attention to privacy and she continued; "I did not have to suffer in the same room with many people. I felt very uncomfortable there while being examined (W-8), Some other participants declared that "All people (other pregnant, health care workers, midwifes, nurses, cleaning staff) could see me easily. It made me feel so bad" (W10), "I would like them to pay more attention to my privacy. The door of service could be locked; however, it was not locked. Anybody could easily enter into the room" (W-1).

The participants stated that during VE process, the lithotomy table, medical equipment (n: 5) and ambient temperature (n: 5) also affect the examination experience of women. One participant mentioned about VE table as; "Obviously, people may imagine the birth (mn lithotomy) table as attractive. But after lying on the birth table, taking the position, opening the legs and experiencing that examination, it feels a little scary" (W-1). Another participant said; "The presence of medical equipment around got me have tension. There was a table on which I saw a knife, a scalpel, and a number of tools that I didn't know. When anybody saw them, I believed that they would inevitably get into panic" (W-8).

Sub Theme 4: Frequency of vaginal examination: It was observed that the participants thought that the VE was frequently (especially just before the birth) performed and they (n: 11) felt uncomfortable. In more detail; "They examined me once every $10 \mathrm{~min}$, this really bothered me and it was a really bad situation" (W-3), "I was constantly checked in and examined. That caused me to feel very restless. It was performed many times before birth" (W-5).

\section{Theme II. Expectations}

Sub Theme 1: Expectations from health professional: The majority of the participants (n: 11) expected a smiling face from the health care professionals. The participant statements related to the smiling face were as; "We wanted them to be friendlier, because we were very excited. I think it would be better" (W-3).

Another expectation of the participants ( $\mathrm{n}$ : 9) was to be formally informed. The participant (W-3) stated; "I wanted them to keep me informed. I wanted them to tell me how and why they perform the VE. Because I was very excited and nervous on the birth table."

Sub Theme 2: Request for emotional support: All of the participants wanted emotional support. Most of the women (n: 10) wanted support from the health professionals during the VE. Their expectations were stated as; "No family member should come with us for the support. The favor of a doctor or a nurse was enough for me. I believed to get the necessary support from them." (W-9), "I did not want any family members. Because I would feel more uncomfortable (laughing). Only medical staff was enough for me." (W-16). Spousal support was the second most expected emotional support (n: 8). Opinions of women on spousal support were as; "I wish I had my husband with me, so I would have got courage from him." (laughing) 
(W-7), "I would love to have my husband with me, but they did not let him. One should not feel alone in that environment" (W-8).

Sub Theme 3: Expectations regarding environment: The participants ( $\mathrm{n}$ : 9) wanted more importance to be given to their privacy due to the being in a foreign environment. Expectations about privacy were: "It would have been better if the examination had been performed behind the curtains." (W-1), "It would have been better if they had performed the examinations with less people around" (W-10).

The second important expectation (n: 6) was the hygiene. Namely, "The environment should be clean. However, that was so" (W-5). As for the expectation about the shape of lithotomy table; "There could be another table that did not scare us." (laughing) (W-1), "The lithotomy table had to be absolutely different because it was so uncomfortable" (W-8).

Another expectation of women was having a private room. That is; "If there were separate rooms, we would have not heard anyone shouting and in fact we would have not seen the others' examinations and we could have kept our privacies" (W-19).

Knowledge is an important tool in controlling the experiences (19). In this study, women were aware of VE and thought the examination was performed both to evaluate the progression of childbirth and to determine gynecological problems. This result is similar to the Hassan et al.'s (6) study finding which shows that $82 \%$ of women have accurate information regarding why VE is performed. In this regard, it can be considered as a positive situation that the participants have information about the VE. However, women's being aware of why VE is performed does not show that they will not experience any anxiety during the examination (19).

Although VE seems as a simple intervention, women are mostly affected negatively $(1,12,13)$. In this study, it was found that women had more negative experiences with VE in accordance with the literatüre. It was seen that the most expressed opinion within the scope of the negative experience was the frequency of VE, and that most women thought that it was made excessively and unnecessarily. This result is consistent with studies showing that women are having VE more frequently than they expect at birth $(1,6,12)$. It is known that unnecessary and frequent VE disturbs women and increases pain and suffer (8). In this study, it was observed that women who thought that VE was done frequently experienced embarrassment and stress. WHO recommends reducing the frequency of VE by giving the importance to the wishes and preferences of women at the birth process (5). Also, in a systematic review, it was found that the evidences related to the role of VE at the regular intervals on the delivery were insufficient (3).

In the present study, the most frequently emphasized negative experience after the frequent VE was violation of privacy. It is very important to ensure privacy especially in maternity clinics where sensitive examinations are performed (20). Ensuring and maintaining patient privacy in healthcare is primarily the responsibility of healthcare professionals (21). In the study, it was observed that women think the health professionals do not pay enough attention to the physical and social privacy, and they want them to behave much more sensitive in this regard. The perception of privacy is affected by culture and religious values in Turkish society $(22,23)$. According to the religion of Islam, one's body is his/her individual and private space. Especially, it may be uncomfortable to touch, look or show to the body of different gender (22). Considering the VE is related to maternal and fetal health even if women allow the examination violating their privacy limits, they are disturbed by this, and experience loss of control (24). Studies show that even if healthcare professionals find it important to protect privacy, they are not cautious in protecting privacy (25). It was also observed that the health professionals were not able to provide physical privacy sufficiently due to the characteristics of the institutions (21). In the present study, it was thought that the failure of the privacy may be related to the acceptance of conditions in the current examination environment as usual. Remembering birth, one of the most important events in human life, as a positive experience is the basic right of a woman. In this research, some participants stated that the health care professionals used verbal violence during the examination, and this affected them negatively and increased their worries seriously. During labor, women may experience negative reactions from healthcare professionals when they try to keep their privacy or fail to do what is said (2). In a study conducted in Palestine, similar to the finding of the study, women were exposed to verbal violence and negative behaviors of the healthcare professionals during VE (6). In this 
and other studies, it was determined that women expect a smiling face, kindness and understanding from the health professionals in the VE process $(11,12,14)$. This result suggests that the healthcare team could not provide enough empathy with women.

For most women, showing the genital organs which they believe to cover and hide throughout life from childhood causes negative emotions during VE process (26). The studies show that the women feel ashamed, guilt, loneliness, discomfort, nervous, stress, anxiety and fear due to the $\operatorname{VE}(6,11,12)$. In this study, in accordance with the literature, it is determined that the most emotional experiences on VE of women are shame and fear.

Health professionals should be much gentler towards the women during the VE due to the fact that they are physically and psychosocially more sensitive (13). Studies shows that the rude and indifferent behaviors of the health professionals and lack of information about the VE are the major reasons of negative VE $(6,8)$. Childbirth is a process that cannot be fully controlled, and the results of which cannot be predicted (27), it is very important to inform the woman about VE. In this study, in accordance with literature, the participants stated that health professionals did not provide the required information about the examination, and they were not kind, friendly, understanding and caring. They emphasized that all these behaviors negatively affected their psychological status and VEs. Studies indicate that in case the women were informed about the VE and related results, and positive communication had been provided with them their negative feelings of fear and anxiety would lessen, and hence they would feel much more relaxed, calm and comfortable $(10,14)$. Similarly, in this study some of women stated they felt relieved after the examination while feeling tense and pain before VE since health workers gave feedback about VE and their empathetic approach. Similar to the findings of this study, Teskereci et al (7). stated that women feel less pain and discomfort if they are informed about the examination results.

Another factor associated with VE experience is the possibility to receive care from the same healthcare professional. In the present study, women examined by the same healthcare professional evaluated $\mathrm{VE}$ as a positive experience whereas those examined by different professionals reported more anxiety and discomfort. This finding is compatible with the results showing that women experience stress and embarrassment in VEs performed by the different healthcare professionals $(6,7,12)$. VE performed by the same healthcare professional may reduce the unnecessary frequency of $\mathrm{VE}$ and prevent the pain and discomfort feelings. Therefore, it should be ensured that healthcare professionals perform their duties as patientcentered rather than job-centered.

One of the affecting factors for the experiences of $\mathrm{VE}$ is the gender of health professionals. In this study, the majority of participants preferred to have the VE performed by the female health professionals as a consequence of the embarrassment, shame and stress senses. Similar to our findings in the literature, it was expressed that the women preferred the female health professionals in the VE due to the feeling of much more comfortable $(11,28)$. Studies also show that women experience lower anxiety, less pain and embarrassment in the VE performed by the female health care professionals $(5,29)$. These results suggest that it is important to consider cultural effects in VE.

Another expectation of women during the VE is emotional support. The participants stated that they would be ashamed of the VE with the presence of their spouse and close family members, and feel uncomfortable. Therefore, the expectation of support from healthcare professionals during the examination process is higher than that of spouse and close family members. This result is also compatible with the literature $(10,26)$. Most maternity units in Turkey, the spouses and relatives are not allowed to enter into due to the hospital policies and cultural reasons. Consequently, it is an expected result that the basic support expectation of women is from health personnel. A study emphasized strongly the importance of sensitive women-centered care (especially in more conservative cultures) during the VE process (4).

The ergonomic environment is important to facilitate VE and the delivery process, reduce fear and increase birth satisfaction (30). Especially in the VEs performed in the maternity ward, the differences in the environmental conditions such as the shape of lithotomy table, color of environment, goods and materials in the delivery room cause the women feel more stress $(31,32)$. Taking into account all the study results provided above, the fundamental quantities given importance are as follows: the doors, windows and lighting system of the childbirth and VE 
rooms should be designed to ensure privacy (31), the rooms should be soundproof, single-room and furnished with furniture to give comfort in the home environment (32-34), the materials used in VE should be sterilized and aceptic $(19,35)$, medical and emergency equipment in the VE environment should be hidden by visual art (36), lithotomy table of VE must be at proper height $(32,34)$, relaxation music should be provided in the environment during the VE process (37). In the present study, in accordance with the literature, the women emphasized the need for the VE environment ensuring the physical and social privacy, the hygiene, private room, ergonomic lithotomy table and relaxing music.

\section{Strength and limitations}

The current study is limited to the opinions of 20 women giving birth, so our results cannot be generalized to all women. However, the study allowed us to clearly understand women's perspective, experiences and expectations on VE. Covering of the both of two public hospitals where births take place in the province reflects the strength of this study. In addition to the evaluations from individuals, the effects of both the service providers and institutional facilities should not be ignored on the improvement of the quality of health services. It is suggested that future researches should be planned to reveal the experience of health professionals about VE and

\section{REFERENCES}

1. Shepherd A, Cheyne H. The Frequency and Reasons for Vaginal Examinations in Labour. Women Birth 2013;26(1):49-54.

2. Bekmezci H, Özkan H. Ebelik Uygulamalarında Mahremiyetin Önemi. Sağlık Bilimleri ve Meslekleri Dergisi 2015;2(1):113-24.

3. Downe S, Gyte GML, Dahlen HG, Singata M. Routine Vaginal Examinations for Assessing Progress of Labour to Improve Outcomes for Women and Babies at Term. The Cochrane Database of Systematic Reviews 2013;15(7):010088.

4. Muliira RS, Seshan V, Ramasubramaniam S. Improving Vaginal Examinations Performed by Midwives. Sultan Qaboos University Medical Journal 2013;13(3):442-9.

5. World Health Organization [Internet]. Geneva; Switzerland. 2014. WHO Recommendations for Augmentation of Labour. [cited 2020 Feb 11]; Available from:

https://apps.who.int/iris/bitstream/handle/10665/ $112825 / 9789241507363$ eng.pdf:jsessionid $=798$ the effects of institutional conditions on these practices.

\section{CONCLUSION}

It was observed that the women had more negative experiences based on the $\mathrm{VE}$ at the childbirth. They thought they were examined frequently and they felt embarrassment and fear. It was determined that the participants expected the support from healthcare professionals and their spouses during the VE process. The most expected features from the healthcare professionals are to be friendly and provision sufficient information in time. Moreover, it was found that the examination environment was expected to be more reliable in terms of privacy. The positive experience of VE during the delivery process positively affects the delivery experience. In this regard, the paying attention to the privacy of women during the VE process, making ergonomic arrangements regarding the birth environment, providing the required care with appropriate communication techniques of healthcare professionals seem to be important for the satisfaction of women from the VE.

Acknowledge: We thank to all women participated in this study.

Conflict of interest: The authors report no actual or potential conflicts of interest.

Author Statements: Study design: GY, NÇB, Data collection: GY, Data analysis: GY, NÇB, Manuscript writing and editing: GY, NÇB.

\section{B39536309BD54E225F1EB340?sequence} $=1$

6. Hassan SJ, Sundby J, Husseini A, Bjertness E. The Paradox of Vaginal Examination Practice During Normal Childbirth: Palestinian Women's Feelings, Opinions Knowledge and Experiences. Reproductive Health 2012;9(16):1-9.

7. Teskereci G, Yangın H, Akpınar A. Experiences of Women Regarding Vaginal Examination During Labor: A Qualitative Study. Health Care Women International 2020;41(1):75-88.

8. Lewin D, Fearon B, Hemmings V, Johnson G. Women's Experiences of Vaginal Examinations in Labor. Midwifery 2005;21(3):267-77.

9. Bonilla-Escobar FJ, Ortega-Lenis D, RojasMirquez JC, Ortega-Loubon C. Panamanian Women's Experience of Vaginal Examination in Labour: A Questionnaire Validation. Midwifery 2016;36(2016):8-13.

10. Yanıkkerem E, Özdemir M, Bingöl H, Tatar A, Karadeniz G. Women's Attitudes and Expectations Regarding Gynaecological Examination. Midwifery 2009;25(5):500-8.

11. Szymoniak K, Cwiek D, Berezowska E. Women's Opinions Regarding Gynaecological 
Examination in a Hospital. Ginekologia Polska 2009;80(7):498-502.

12. de Klerk H, Boere E, van Lunsen R, Bakker J. Women's Experiences with Vaginal Examinations During Labor in the Netherlands. Journal of Psychosomatic Obstetrics and Gynecology 2018;39(2):90-5.

13. Ying Lai C, Levy V. Hong Kong Chinese Women's Experiences of Vaginal Examinations in Labour. Midwifery 2002;18(4):296-303.

14. Güneş G, Karaçam Z. Doğum Sonu Dönemdeki Kadınların Vajinal Muayene Deneyimleri: Nitel Bir Araştırma. Dokuz Eylül Üniversitesi Hemşirelik Yüksekokulu Elektronik Dergisi 2018;11(2):87-95.

15. Chen CH, Wang SY, Chang MY. Women's Perceptions of Helpful and Unhelpful Nursing Behaviors During Labor: A Study in Taiwan. Birth 2001;28(3):180-5.

16. Lathlean J. Qualitative analysis. In Gerrish K, Lathlean J, eds. The Research Process in Nursing. 7th ed. London: Wiley-Blackwell Publishing; 2015. p. 471-88.

17. Saunders B, Sim J, Kingstone T, Baker S, Waterfield J, Bartlam B, et al. Saturation in Qualitative Research: Exploring Its Conceptualization and Operationalization. Quality \& Quantity 2018;52(4):1893-907.

18. Polit DF, Beck CT. Nursing research, principles and methods. 8th ed. Philadelphia: Lippincott Williams and Wilkins; 2013.

19. Sarpkaya D, Vural G. Hemşirelikte Dört Bilme Yolunun Jinekolojik Muayenede Kullanımı. Dokuz Eylül Üniversitesi Hemşirelik Yüksekokulu Elektronik Dergisi 2014;7(2):1247.

20. Hartigan L, Cussen L, Meaney S, O’Donoghue K. Patients' Perception of Privacy and Confidentiality in the Emergency Department of a Busy Obstetric Unit. BMC Health Services Research 2018;18(1):1-6.

21. Arslan ET, Demir H. Attitudes of Health Workers Related to Patient Confidentiality: A Qualitative Research. Bolu Abant İzzet Baysal University Journal of Graduate School of Social Sciences 2017;17(4):191-220.

22. Şen Y. İslâm Hukukuna Göre Sağlık Hizmetlerinde Mahremiyet Hakk1 Ekev Akademi Dergisi 2015;19(61):425-50.

23. Bostan S, Unal C. Awareness and Attitude of Patients about Patient Privacy. Turkiye Klinikleri Journal of Medical Ethics-Law and History 2019;27(3):239-49.

24. Kilpi HL, Valimaki M, Dassen T, Gasull M, Lemonidou C, Scott A. et al. Privacy: a Review of the Literature. International Journal of Nursing Studies 2001;38(6):663-71.
25. Kim K, Han Y, Kim JS. Nurses' and Patients' Perceptions of Privacy Protection Behaviours and Information Provision. Nursing Ethics 2017;24(5):598-611.

26. Erbil N, Şenkul A, Sağlam Y, Ergül N. Determination of Attitudes with Gynecologic Examination and Anxiety of Turkish Women Before Gynecologic Examination. Journal of Human Sciences 2008;5(1):1-5.

27. Nilsson C, Hessmen E, Sjöblom H, Dencker A, Jangsten E, Mollberg M, et al. Definitions, Measurements and Prevalence of Fear of Childbirth: A Systematic Review. BMC Pregnancy and Childbirth 2018;18(28):2-15.

28. Turgut N, Gölbaşı Z. Aspects of Emotional and Physical Discomfort in Gynecologic Examination: A Study of Turkish Women. The Journal of Obstetrics and Gynaecology Research 2014;40(6):1777-84.

29. Demir S, Oskay UY. Jinekolojik Muayene Olan Kadınların Yaşadığı Deneyimler ve Sağlık Profesyonelinden Beklentileri. Kadın Sağlığ1 Hemşireliği Dergisi 2014;1(1):68-79.

30. Bilgin NÇ. Ergonomics in delivery rooms and its importance. In Çamlı AA, Ak B, Arabacı R, Efe $\mathrm{R}$, eds. Recent advances in health sciences. Sofia: St. Kliment Ohridski University Press; 2016. p. 174-82.

31. Larkin P, Begley CM, Devane D. Women' Experiences of Labour and Birth: An Evolutionary Concept Analysis. Midwifery 2009;25(2):49-59.

32. Çitak Bilgin N, Böyük M. Doğum Ünitelerinde Ergonomi: Riskler, Etkiler ve Öneriler. Yaşam Boyu Hemşirelik Dergisi 2020;1(1):25-45.

33. Setola N, Iannuzzi L, Santini M, Cocina GG, Naldi E, Branchini L, et al. Optimal Settings for Childbirth. Minerva Ginecologica 2018;70(6):687-99.

34. Jenkinson B, Josey N, Kruske S. Birth Space: An Evidence-Based Guide to Birth Environment Design. Brisbane QLD, Australia: Queensland Centre for Mothers \& Babies, The University of Queensland 2014.

35. Gedey S. Labor-Delivery-Recovery Room Design That Facilitates Non-Pharmacological Reduction of Labor Pain: A Model Labor Room Plan and Recommended Best Practices. Perkins+Will Research Journal 2014;1:127-39.

36. Duncan J. The Effect of Colour and Design in Labour and Delivery: A Scientific Approach. Optics \& Laser Technology 2011;43(2):420-4.

37. Kocabaş P, Khorshid L. Comparison of the Effects of a Special Gynecological Garment and Music in Reducing the Anxiety Related to Gynecological Examination. Journal of Clinical Nursing 2012;21(5-6):791-7. 